Raymond Bjuland

Institutt for grunnskolelcererutdanning, idrett og spesialpedagogikk,

Universitetet i Stavanger

Nina Helgevold

Institutt for grunnskolelcererutdanning, idrett og spesialpedagogikk,

Universitetet i Stavanger

Elaine Munthe

Det humanistiske fakultet, Universitetet i Stavanger

\title{
Lesson Study og lærerstudenters fokus på elevers læring i veiledningssamtaler
}

\section{Sammendrag}

Søkelyset settes her på norsk grunnskolelcererutdanning og på veiledningssamtaler i praksisopplaring hvor Lesson Study ble innført som arbeidsmetode. Veiledningssamtaler i matematikk og naturfag analyseres ut fra et teoretisk rammeverk om hva som har betydning for elevers laring (Bransford, Brown, \& Cocking, 2000). Dette gir et grunnlag for å identifisere elevsentrerte, kunnskapssentrerte og vurderingssentrerte ytringer. Ytringene blir i tillegg knyttet til tre sentrale aspekter ved planlegging og gjennomføring av en forskningstime i en Lesson Study syklus: studentenes forskningsspørsmål, deres prediksjon av hva som kan forventes av elevene i forhold til dette lceringstemaet og hvordan de vil observere elevenes laring. Analysene påpeker interessante forskjeller mellom studentgruppene på tvers av de to fagene. Studentene i matematikk valgte å legge opp undervisningen ut ifra larebokens nivåinndeling av lerestoffet, noe som ser ut til å virke hemmende med tanke på elevobservasjon og prediksjon knyttet til det faglige emnet. Studentene i naturfag var mer opptatt

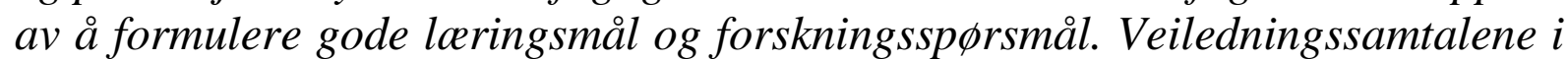
naturfag hadde også et tydelig fokus på prediksjon samt aktiv elevobservasjon under gjennomføringen av undervisningsøkten. Resultater fra denne studien drøftes i forhold til hvordan lærerutdannere på campus og i praksisskoler bidrar til lererstudenters muligheter for utvikling av nødvendig kompetanse for å kunne arbeide på forskningsbaserte måter $i$ skolen. Resultatene viser også betydningen av å følge opp implementering av nye tiltak i lcererutdanninger.

Nøkkelord: Praksisopplæring, grunnskolelæererstudenter, Lesson Study 


\begin{abstract}
In this article, we present a study of field practice during Initial Teacher Education in Norway where Lesson Study was implemented. Mentoring sessions in mathematics and science were analyzed based on a theoretical framework that highlights pupils' learning (Bransford, Brown, \& Cocking, 2000). This framework was used as an analytical tool to identify pupil-oriented, knowledgeoriented and assessment-oriented utterances. Such utterances were also related to three crucial aspects of planning and carrying out a research lesson in a Lesson Study cycle: the student teachers' research questions, their predictions of possible difficulties that might arise in relation to the learning goal and how they intend to observe pupils' learning. The analyses of the mentoring sessions show interesting differences between the student groups across the two subjects. The students in mathematics based their teaching on the textbook's division of task levels, something that seems to have a restraining effect on pupil observation and prediction related to mathematical goals and content. The students in science were more concerned with formulating adequate learning goals and research questions. The mentoring sessions in the science groups also had a clear focus on prediction and pupil observation during the research lesson. Results of this study are discussed in relation to how faculty teachers and mentoring teachers in field schools contribute to student teachers' developing the competence needed to work in research-based ways in schools. The results also show the importance of following up the implementation of new working methods in Initial Teacher Education programs.
\end{abstract}

Key words: Field practice, studeteachers, Lesson Study

\title{
Innledning
}

Et hovedmål for grunnskolelærerutdanningene er at de skal kvalifisere til forskningsbasert yrkesutøvelse (Kunnskapsdepartementet, 2010). Norge er et av få land som er så spesifikk på at yrkesutøvelse i grunnopplæring skal være basert på forskning (Munthe \& Rogne, 2015). Lærerutdanningenes oppgave er dermed å finne fram til gode måter å nå dette målet på. Ståstedet som er tatt $\mathrm{i}$ studien som presenteres her, er at det å kvalifisere til forskningsbasert yrkesutøvelse er en oppgave som lærerutdannere ved høgskoler og universiteter må samarbeide med lærerutdannere i praksisskoler om.

Dette samarbeidet kan være en utfordring for lærerutdannere på begge læringsarenaene (campus og praksisskole). Både studier gjort i USA (for eksempel Feiman-Nemser \& Buchman, 1985) og nasjonalt (for eksempel Ohnstad \& Munthe, 2010; Sundli, 2007) finner at en av fallgropene i praksisopplæring er at opplæringen ikke gir god nok anledning til å studere, analysere og utvikle kritisk kunnskap, men heller fører til at studenter overtar den praksis 
som de kvalifiseres innen. Lærerutdannere på campus har varierende grad av muligheter til forskning i skoler som kan gi dem nødvendig innsikt i lærerarbeidet som foregår i skolene. Det er flere som framhever hvor vanskelig det er å sikre rekruttering av lærerutdannere som både har en $\mathrm{PhD}$ og didaktisk kompetanse, og lærerutdannere i praksisskoler har lite eller ingen forskningserfaring (Følgegruppen, 2013).

Et treårig forskningsprosjekt ved Universitetet i Stavanger ("Teachers as Students" - TasS) har tatt tak i denne problematikken. Definisjonen av "kvalifisering til forskningsbasert yrkesutøvelse" i prosjektet, er at lærerstudenter lærer å studere undervisning på måter som gir dem innsikt i hvordan de kan støtte opp om læring hos elever. Dette er en "inquiry-basert" form for systematisk utforsking og læring. I TasS prosjektet er det benyttet et tidsforskjøvet eksperimentelt design. Dette omfattet: (1) En studie av normalsituasjonen i studentenes undervisningspraksis (kontrollgruppe, gjennomført våren 2012), etterfulgt av (2) en intervensjon som var inspirert av Lesson Study (intervensjonsgruppe, gjennomført våren 2013) (Murata \& Pothen, 2011; Stigler \& Hiebert, 1999).

Foreløpige resultater av analyser fra alle veiledningssamtaler i intervensjonssituasjonen viser endringer sammenlignet med veiledningssituasjoner i kontrollgruppen, men at det også er variasjon i intervensjonsgruppen. Det som kjennetegner intervensjonen er større grad av studentsamarbeid og fokus på faglige læringsmål der studentene retter oppmerksomheten mot elevenes læring (Helgevold, Næsheim-Bjørkvik, \& Østrem, 2013). Innledende analyser ble gjort gjennom "tynne” beskrivelser (Rivera \& Tharp 2004) av det empiriske materialet. Det ble utviklet en observasjonsprotokoll til registrering av innhold og samtaleaktiviteter i de ulike veiledningssamtalene. Resultatene fra denne studien er brukt for å velge ut veiledningsøkter som kan være av interesse for mer dyptpløyende analyser. I denne artikkelen har vi valgt å studere veiledningssamtaler i naturfag og matematikk fordi det ser ut til å være forskjell særlig mellom disse to fagene når det gjelder elevfokus og faglig innhold i samtalene. Forskningsspørsmål som har ledet arbeidet som presenteres her er: Hva kjennetegner veiledningssamtalene i matematikk og naturfag og hvordan kan vi forklare forskjellene?

\section{Teoretisk bakgrunn}

Lesson study er en systematisk læringsform for lærere som tar utgangspunkt i planlegging og studie av instruksjon og læring (Murata \& Pothen, 2011; Stigler \& Hiebert, 1999). I TasS-prosjektet er dette forstått som et svar på forventningene om analyse og utvikling av kritisk kunnskap og dermed også kravet om å kvalifisere til forskningsbasert yrkesutøvelse når vi forstår forskningsbasert som en "inquiry” basert arbeidsmåte (Munthe \& Rogne, 2015). 
Selv om Lesson Study tradisjonelt er mest kjent og mye brukt i forbindelse med profesjonell læring for lærere i Japan, er Lesson Study også i ferd med å finne sin plass i japanske lærerstudenters praksisskoler (såkalte Fuzoku skoler) (Elipane, 2011). Det er også rapportert om gode erfaringer med bruk av Lesson Study blant amerikanske lærerstudenter (Murata \& Pothen, 2011).

I en Lesson Study syklus kommer en gruppe lærere sammen for å planlegge, gjennomføre og observere, for deretter å drøfte observasjoner, vurdere mulige endringer for å få bedre innsikt eller bedre resultater, raffinere og prøve ut på nytt og til slutt å formidle om en undervisningsøkt eller en forskningstime som den også blir kalt (Munthe \& Postholm, 2012). I den kollektive planleggingen som foregår i Lesson Study grupper, er det å definere forskningsspørsmål som lærerne vil finne ut av gjennom observasjon i forskningstimen, prediksjon av elevers reaksjoner på hva som planlegges og hvordan gjennomføre observasjon for å få svar på forskningsspørsmålene tre helt sentrale komponenter. Prediksjon er kanskje litt uvant for norske lærerstudenter og lærere i en planleggingsfase. Dette kan forstås som "hypoteser" som framsettes i forkant av forskningstimen (den undervisningstimen som skal studeres) og som bidrar til å få fram lærernes/lærerstudentenes egne forforståelser. Ved å være mer eksplisitt på egne forforståelser om elevers forståelse eller læringsmuligheter eller reaksjoner, kan det være enklere for lærerstudenter å utvikle egen forståelse gjennom observasjon. Denne informasjonen er nyttig med tanke på å kunne studere konsekvenser av valgene som blir bestemt under planleggingen (Munthe \& Postholm, 2012).

Hensikten med Lesson Study er å forbedre læringsmuligheter for elever. Vi benytter derfor et teoretisk rammeverk som har identifisert hva som kjennetegner undervisning som har betydning for elevers læring (Bransford et al., 2000). Lærere som er bevisst på det elevsentrerte perspektivet vil i sin undervisning være opptatt av kunnskaper, ferdigheter og holdninger som elevene tar med seg inn i klasserommet. Dette omfatter blant annet elevenes forkunnskaper til det faglige emnet, men også elevenes individuelle forskjeller og ulike kulturelle bakgrunn. Bransford et al. (2000) viser til diagnostisk undervisning som et eksempel på hvordan en starter undervisningen med utgangspunkt i elevenes kunnskapsstrukturer. En slik undervisning tar sikte på å diagnostisere (elevene) gjennom observasjon, spørsmål og samtaler og gjennom refleksjon over resultat av undervisningen. I et elevfokusert læringsmiljø vil læreren respektere og forsøke å forstå elevers tidligere erfaringer og forståelse, slik at disse utgjør det fundamentet som nye forståelser kan bygges på.

Et elevsentrert perspektiv må koples sammen med et kunnskapssentrert perspektiv hvor "attention must be given to what is taught (information, subject matter) why it is taught (understanding), and what competence or mastery looks like” (Bransford et al., 2000, s. 24). Dette perspektivet fokuserer på hva slags informasjon og hvilke aktiviteter som støtter elevene i å utvikle en forståelse for det disiplinfaglige og er opptatt av at lærere må ha en kritisk tilnærming til 
eksisterende læreplaner. I et kunnskapssentrert læringsmiljø vektlegges elevenes meningsskaping og utvikling av metakognitive ferdigheter. Også vesentlig er "learning the landscape" (Greeno sitert i Bransford et al., 2000, s.139). Elevers utvikling av kunnskap og forståelse krever et nettverk av sammenhenger som kopler egen forståelse opp mot et større "landskap”. I tilrettelegging av kunnskapssentrerte læringsmiljø vil det alltid være utfordrende å finne et gunstig balansepunkt mellom aktiviteter som skal bidra til utvikling av elevers forståelse og aktiviteter som støtter elever i automatisering av nødvendige funksjonelle ferdigheter.

Det vurderingssentrerte perspektivet er et tredje kjennetegn på en læringsfremmende undervisning der lærere er opptatt av formativ vurdering som har til hensikt å synliggjøre for både lærere og elever hva elevene kan. Et vesentlig poeng her er at vurdering og tilbakemelding knyttes til elevers forståelse og ikke til i hvilken grad eleven kan gjengi prosedyrer og faktakunnskap. Tilbakemeldinger til elever bør forekomme kontinuerlig og være integrert i selve undervisningen, den er mest verdifull når elevene gis mulighet til revidere egen tenkning og forståelse i selve læringsprosessen. Effektive lærere forsøker gjennom sin undervisning å lære mer om hva elevene tenker og forstår, og ifølge Bransford et al. (2000, s. 24) vil "formative assessments help both teachers and students monitor progress".

Bransford et al. (2000) løfter også fram det fellesskapssentrerte perspektivet som et fjerde kjennetegn på en læringsfremmende undervisning. Disse forskerne bruker betegnelsen "community-centered environments" som viser både til læringsmiljøet i en klasse, på en skole, men også til det nærmiljøet som skolen er en del av. Elevers læring styrkes gjennom at det etableres sosiale normer som verdsetter elevers utforsking og muligheter til å gjøre feil. I hvilken grad fellesskapssentrerte læringskulturer vektlegges i det enkelte klasserom må også sees i perspektiv av hvordan den overordnede samfunnskulturen påvirker normer i klasserommet.

Begrepene fra Bransford et al. (2000) vil utgjøre analytiske begreper for å studere hva som karakteriserer veiledningssamtaler i matematikk og naturfag.

\section{Metode}

I datainnsamlingen i TasS prosjektet våren 2013 deltok to praksisgrupper fra hvert av de fire fagene matematikk, naturfag, engelsk og kroppsøving. Studenter og praksislærere er selvselekterte til å delta i studien. Alle gruppene deltok i gruppeintervju før og etter praksisopplæringsperioden i det som var deres fjerde semester. Det ble gjort videoopptak av førveiledning, selve forskningstimen som de gjennomførte, mellomveiledning for endring, ny forskningstime og etterveiledning. Vi har selektert et utvalg av materialet. Seleksjonen er gjort med utgangspunkt i en tidligere studie av innhold i veiledningsøkter på et mer over- 
ordnet plan ved hjelp av "tynne” beskrivelser (Helgevold et al., 2013). I denne artikkelen studerer vi nærmere forskjeller som ble identifisert. Datamaterialet i denne studien består av førveiledningssamtaler i to praksisgrupper i matematikk og førveiledningssamtaler i to praksisgrupper i naturfag. En praksislærer er veileder i hver gruppe.

\section{Deltakere}

De to praksisgruppene i matematikk bestod av henholdsvis tre og fire studenter. Studentene var alle tilknyttet Grunnskolelcererutdanning 5-10 og hadde gjennomført 60 studiepoeng i faget (GLU 5-10, matematikk 1 og matematikk 2). Studentene hadde siste eksamen i matematikk i tredje semester, men de har imidlertid praksisopplæring i matematikk også i sitt fjerde semester. Siden studentene ikke hadde undervisning i matematikk på campus i det fjerde semesteret, fikk de i liten grad innføring i Lesson Study med fokus på matematikkfaget i forkant av praksisopplæringsperioden.

Den ene praksisgruppen i naturfag bestod av fire studenter som alle var tilknyttet Grunnskolelcererutdanning 1-7. Den andre praksisgruppen i naturfag bestod av tre studenter som alle var tilknyttet Grunnskolelcererutdanning 5-10. Alle studentene var i sitt fjerde semester, og studentene hadde startet med naturfag våren 2013. Før praksis hadde begge studentgruppene en åtte ukers undervisningsperiode innen kjemi, geofag og teknologi på campus. I denne undervisningsbolken hadde studentene også fått innføring i Lesson Study der det ble vist eksempler på gjennomføring av en Lesson Study syklus. Faglærer på campus hadde også gitt studentene en presentasjon av et skjema (CoRe-Content Representation, for en grundigere beskrivelse, se Loughran, Berry, \& Mulhall, 2012). I et slikt CoRe-skjema skal studentene blant annet svare på hva de ønsker at elevene skal lære om med tanke på en eller flere naturfaglige ideer eller begreper, og hvorfor det er viktig at elevene lærer dette. Videre skal studentene reflektere over mulige begrensninger relatert til å undervise disse ideene, og hvilke læringsaktiviteter som kan være nyttige å bruke med tanke på at elevene skal lære om de naturfaglige ideene eller begrepene.

De fire praksislærerne som inngår i studien hadde alle deltatt på tre samlinger sammen med faglærere på universitetet i forkant av praksisopplæringsperioden våren 2013. På den første samlingen ble det orientert om TasS prosjektet og gitt en innføring i Lesson Study som arbeidsmåte. Den andre samlingen hadde fokus på å tilpasse denne arbeidsmåten til lærerstudenters praksisopplæring. Både på denne samlingen og på den tredje samlingen arbeidet praksislærere og faglærere med å utvikle selve framgangsmåten som vi ville bruke i intervensjonen. 


\section{Intervensjonsdesignet fra planlegging til førveiledning}

Som nevnt ovenfor, er Lesson Study en måte å bidra til systematisk utforsking og læring for lærere. Å kunne predikere elevreaksjoner er en vesentlig del av planleggingsfasen. Dette kan innebære å hente inn forskningslitteratur om elevers læring eller misforståelser, og det kan innebære å bruke egen erfaring. Lærerstudenter har liten erfaring å basere prediksjoner på, og det ble derfor bestemt at lærerstudentene på forhånd skulle intervjue praksislærere om elevers læring, om hvilke forkunnskaper elevene allerede hadde om det temaet som lærerstudentene skulle undervise om. Selve temaet som studentene skulle undervise om, måtte derfor være bestemt på forhånd. På den måten kunne også faglærere bidra med forskningslitteratur som studentene kunne ha bruk for.

Studentene skulle så utarbeide en detaljert plan for selve forskningstimen uten å vite hvem som skulle være ansvarlig for selve undervisningen. De måtte planlegge slik at hvem som helst av dem kunne ta den rollen. Planleggingen skulle innebære at de vurderte aktuelt læringsmateriell, og de skulle søke kunnskap om det faglige emnet i lærebøker eller andre undervisnings- og forskningsressurser. Undervisningen skulle ivareta overordnede mål for elevenes læring, og studentene fikk et eksempel på et plandokument som de kunne anvende i arbeidet. I plandokumentet kunne studentene føre opp det forskningsspørsmålet som de hadde for timen, hva de predikerte om elevenes reaksjoner til ulike tider i undervisningen, og hva som ville være viktig å observere.

Studentene fikk først vite hvem som skulle undervise selve forskningstimen på slutten av førveiledningssamtalene. Dette ble avgjort ved loddtrekning. De andre studentene hadde ansvar for observasjoner under gjennomføringen. Det er vanlig at Lesson Study gjennomføres slik i eksisterende lærerteam. Det er konsekvensene av de valgene som alle har vært med på å ta som skal være i fokus i observasjonene, ikke læreren (Munthe \& Postholm, 2012; Munthe, Baugstø \& Haldorsen, 2013). Det er derfor spesielt viktig at alle har et eierforhold til undervisningen som gjennomføres.

Praksislærerne og studentene hadde fått et hefte om Lesson Study i forkant. I dette heftet fikk lærerne noen tips til hvordan de kunne gjennomføre førveiledningssamtalen, for eksempel type spørsmål som det ville være viktig å arbeide med for å få fram forskningsspørsmål, prediksjon og observasjon på måter som kunne hjelpe studentene til å reflektere over elevers læring i forhold til det emnet som var tema for undervisningen.

\section{Data og analyser}

Materialet som inngår i denne delstudien er videoopptak av fire førveiledningssamtaler $\mathrm{i}$ to fag. Transkripsjonene fra disse veiledningssamtalene danner utgangspunkt for våre analyser. 
Studentgruppen ved skole 1 tilknyttet matematikk planla å gjennomføre en undervisningsøkt (studentene bruker ikke betegnelsen forskningstime) på 10 . trinn der målet for timen er at elevene skal lære om proporsjonalitet ( $\mathrm{y}=\mathrm{ax})$ og proporsjonale størrelser. Studentene ved skole 2 tilknyttet matematikk planla å gjennomføre en undervisningsøkt på 10. trinn (studentene bruker ikke betegnelsen forskningstime) der de i sitt plandokument skriver at målet er at elevene skal "kunne faktorisere og forkorte enkle og avanserte uttrykk". Det er verdt å merke seg at ingen av studentgruppene i matematikk skriver noe om hva som er deres forskningsspørsmål. Det kommer heller ikke fram fra plandokumentene hvordan de vil observere elevene gjennom undervisningsøkten.

Den ene gruppen i naturfag planla å gjennomføre en forskningstime på 6 . trinn (studentene bruker selv begrepet forskningstime i plandokumentet) med et tematisk fokus om begreper knyttet til energi. De har i sitt plandokument utformet to forskningsspørsmål som de ønsker å lære mer om: a) "hvordan elevene oppfatter abstrakte fenomener og hvordan vi best kan legge til rette for at de skal forstå” og b) "hvordan man tar tak i elevenes hverdagsforestillinger. Bli bevisste på dem og rette opp i misforståelser og bygge videre på forestillinger de har som har noe riktig i seg". Den andre praksisgruppen i naturfag planla å gjennomføre en undervisningsøkt (de bruker betegnelsen "en dobbeltime” i plandokumentet) på 90 minutter på 10. trinn der målet med undervisningsøkten er at elevene skal lære at summen av energi er alltid den samme. Videre skal elevene lære om sammenhengen mellom bevegelsesenergi og stillingsenergi. Denne studentgruppen har heller ikke formulert noe forskningsspørsmål.

Analysene har identifisert ytringer som både er elevsentrerte og kunnskapssentrerte (E, K), eller elevsentrerte og vurderingssentrerte (E, V). I tillegg identifiserer vi også ytringer som inneholder både en elevsentrert, kunnskapssentrert og vurderingssentrert komponent (E, K, V). I våre analyser har vi ikke identifisert fellesskapssentrerte ytringer siden dette perspektivet er vanskelig å definere på ytringsnivå på grunn av dets fokus på det som skjer både i klasserommet (mikronivå) og utenfor klasserommet (makronivå). Vi kan imidlertid gjennom å presentere noen utdrag fra veiledningssamtalene få et inntrykk av om studentene i sin planlegging er opptatt av en utforskende og fellesskapsorientert praksis der studentene ønsker at elevene skal drøfte og samhandle.

Tabell 1 illustrerer eksempler på det vi har definert som ytringer. En ytring varer vanligvis så lenge en av deltakerne har ordet. Det kan imidlertid forekomme at en av deltakerne (særlig praksislærerne) snakker forholdsvis lenge. Vi har derfor valgt å bryte opp en lang sammenhengende ytring i flere ytringer der det er et naturlig skifte i fokus innenfor ytringen. Det første eksempelet fra tabellen (90. MP1) betyr ytring 90 fra veiledningssamtale i matematikk (M), der det er praksislærer (P) fra skole 1 som snakker. De tre andre praksislærerne blir på samme måte identifisert som MP2. NP1, NP2. Når 
det gjelder studentene, betyr 28. NS4 ytring 28 fra veiledningssamtale i naturfag der det er student 4 som snakker fra skole 1.

Tabell 1: Eksempler på ytringer knyttet til begrepene fra Bransford et al. (2000)

\begin{tabular}{|l|l|l|}
\hline $\begin{array}{l}\text { 90. } \\
\text { MP1: }\end{array}$ & $\begin{array}{l}\text { Ja. For det er jo det en kan bruke dette til, for det kan være greit å få fram i begynnelsen } \\
\text { av timen også, at målet, eh, de (elevene) skal lære, målet for timen er å lære om } \\
\text { proporsjonale størrelser, og vise hvordan det enkelt kan brukes i dagliglivet. }\end{array}$ & $\begin{array}{l}\mathrm{E}, \\
\mathrm{K}\end{array}$ \\
\hline $\begin{array}{l}\text { 27. } \\
\text { NP1: }\end{array}$ & $\begin{array}{l}\text { Men du vil at elevene skal få forstå .... For jeg ser tydelig igjen de målene dere har valgt } \\
\text { i begynnelsen. Altså det dere har tenkt som et hovedmål for timen, ser jeg tydelig igjen } \\
\text { i forhold til de mål i setter opp i planen. Og da har jeg rett og slett lyst til å hoppe rett på } \\
\text { vurdering ... Hva hadde dere tenkt om det, for nå har dere jo målene. Hvordan skal dere } \\
\text { få til å vurdere elevene ut ifra målene? }\end{array}$ & $\mathrm{E}$ \\
\hline $\begin{array}{l}\text { 28. } \\
\text { NS4: }\end{array}$ & $\begin{array}{l}\text { Jeg tror vi har tenkt at den oppgaven på aktivitet syv, den gruppeoppgaven, der de } \\
\text { (elevene) skal tegne eller skrive og forklare en energikjede. Og så velger de seg ut en } \\
\text { overføring i den og forklarer det nærmere da. Det viser ganske godt om de har forstått } \\
\text { forskjellen på energikjede og energioverføring i hvert fall, mye kommer frem i den } \\
\text { oppgaven. }\end{array}$ & $\begin{array}{l}\mathrm{E}, \\
\mathrm{V}\end{array}$ \\
\hline
\end{tabular}

Første og andre forfatter kodet de fire førveiledningssamtalene hver for seg for deretter å komparere. Kodinger viste seg å være sammenfallende for de to matematikkgruppene. Veiledningene i naturfag var vanskeligere å kode siden studentene bidrog med innspill som bygde på hverandres ideer. Vi bestemte oss derfor for å trekke inn den lokale konteksten som ytringen var en del av. Ytring 57 fra praksislærer ved skole 1 i naturfag kan illustrere dette: 57. NP1: ”Kan vi vurdere elevene på en måte opp imot de begrepene”? En av studentene har i den foregående ytringen fokusert på bevegelsesenergi og stillingsenergi. Derfor ble vi enige om å kode denne ytringen som E, K, V siden "de begrepene" må ses $\mathrm{i}$ lys av studentytringen.

\section{Resultater}

Tabell 2 viser hvor mange ytringer i de fire førveiledningssamtalene som kan identifiseres som elevsentrert, kunnskapssentrert eller vurderingssentrert. Vi leser for eksempel fra tabellen at praksislærer og studentene i naturfaggruppen ved skole 2 (NP2, NS5,6,7) hadde 27 ytringer med et elevsentrert, kunnskapssentrert og vurderingssentrert fokus av totalt 147 ytringer i veiledningssamtalen. Dette viser at $18,4 \%$ av ytringene er identifisert innenfor de tre analysekategoriene. Denne oversikten viser også at begge førveiledningssamtalene i naturfag $(10,9 \%$ og 18,4\%) har et større samtalefokus på elevers læring av det faglige emnet sammenlignet med studentgruppene tilknyttet matematikk $(5,7 \%$ og 8,3\%). Disse resultatene viser at våre analyser med Bransford et al. (2000) som teoretisk og analytisk rammeverk bekrefter tidligere analyser med tynne beskrivelser (Helgevold, Næsheim-Bjørkvik, \& Østrem, 2013). 
Tabell 2: Resultater av ytringer knyttet til begrepene fra Bransford et al. (2000)

\begin{tabular}{|l|c|c|c|c|}
\hline & Skole 1, Mat. & Skole 2, Mat. & Skole 1, Nat. & Skole 2, Nat. \\
\hline & MP1, MS1,2,3 & MP2, MS4,5,6,7 & NP1, NS1,2,3,4 & NP2, NS5,6,7 \\
\hline (E, K) & 10 & 11 & 14 & 20 \\
\hline (E, V) & 0 & 4 & 17 & 6 \\
\hline (E, K, V) & 3 & 1 & 10 & 1 \\
\hline Relativ frekvens & $13 / 230$ & $16 / 193$ & $41 / 376$ & $27 / 147$ \\
\hline Prosent & $5,7 \%$ & $8,3 \%$ & $10,9 \%$ & $18,4 \%$ \\
\hline Varighet & $20: 54$ & $33: 43$ & $54: 18$ & $31: 31$ \\
\hline
\end{tabular}

Det er viktig å understreke at de fire veiledningssamtalene har ulik varighet noe som selvsagt må tas i betraktning (se tabell 2). Vi mener imidlertid at den relative frekvensen av slike ytringer gir en indikasjon på et elevsentrert, kunnskapssentrert og vurderingssentrert fokus i veiledningssamtalene.

Denne oversikten gir et innblikk i noen karakteristikker ved samtalene, men for å beskrive veiledningssamtalene bedre, vil vi analysere ytringer i forhold til viktige aspekter ved planlegging i en Lesson Study syklus, nemlig utvikling av forskningsspørsmål, prediksjon og planlegging av observasjon.

\section{Forskningsspørsmål og observasjoner}

Det er bare i den ene naturfaggruppen at studentene har eksplisitt skrevet ned forskningsspørsmål i plandokumentet de har med seg til førveiledningen. I den andre naturfaggruppen diskuteres målet for timen, og studentene sammen med praksislærer kommer frem til at målet for elevenes læring er å kunne forstå og skille mellom bevegelsesenergi og stillingsenergi. I begge naturfaggruppene vektlegges observasjoner i førveiledningen, og studentene utfordres av praksislærerne til å være spesifikke på hvordan de har tenkt å observere og vurdere elevene ut i fra læringsmålene for forskningstimen. En sekvens fra samtalen i praksisgruppen ved skole 1 illustrerer dette:

27. NP1: Men du vil at elevene skal få forstå. (.) For jeg ser tydelig igjen de målene dere har valgt i begynnelsen. Altså det dere har tenkt som et hovedmål for timen, ser jeg tydelig igjen i forhold til de mål dere setter opp i planen. Og da har jeg rett og slett lyst til å hoppe rett på vurdering. Hva hadde dere tenkt om det, for nå har dere jo målene. Hvordan skal dere få til å vurdere elevene ut ifra målene? (E, V)

28. NS4: Jeg tror vi har tenkt at den oppgaven på aktivitet syv, den gruppeoppgaven, der de skal tegne eller skrive og forklare en energikjede. Og så velger de seg ut en overføring i den og forklarer det nærmere da. Det viser ganske godt om de har forstått forskjellen på energikjede og energioverføring i hvert fall, mye kommer frem i den oppgaven. (E, K, V)

29.NS3: Håper vi.

30. NP1: Ja. (.) Fordi at jeg ser at hvis. Hvis vi går på Newtons vugge, i planen, aktivitet to. Og så står det mål: vekke undring og lære om hypoteser og en energioverføring, ikke sant. Og så står der noe om observere, altså vurdering, observere, se, hører. Og så tenker jeg, altså hva legger dere i de (.) Altså hva tenker dere om vurdering når dere skriver det, sånn der? $(\mathrm{E}, \mathrm{K}, \mathrm{V})$ 
31. NS2: Vi har jo tenkt litt på de tre som faktisk går rundt og observerer.(.) og at de får med seg ganske mye.

32. NP1: Og hva skal de observere da?

33. NS1: Det har vi laget i et eget skjema.

Praksislærer går her konkret inn i plandokumentet og utfordrer studentene til å forklare hvordan de skal observere og vurdere elevenes måloppnåelse (27), (30). I denne gruppen hadde studentene utviklet et eget observasjonsskjema knyttet spesifikt til læringsmålene som var satt opp og elevenes konkrete arbeid med læringsaktiviteter i klasserommet. I den andre naturfaggruppen har ikke studentene utviklet et eget observasjonsskjema, men praksislærer er tydelig på at studentene må planlegge observasjoner før timen, 123. NP2: "Det dere, det dere også må tenke på er... hva slags observasjoner skal dere ta i de timene, ikke sant vel... altså hva er det dere skal se etter?..."

I matematikkgruppene diskuteres tema, aktiviteter og oppgaver som skal gjøres i forskningstimen, uten at læringsmål for forskningstimen presiseres. I den ene studentgruppen kommer hverken praksislærer eller studenter inn på observasjoner i klasserommet som en måte å innhente informasjon om elevenes læring på. I stedet omhandler svært mange av ytringene utsagn om elevers faglige nivå og elevers atferd slik som ytring 31. MS3: "Vi sier at de som føler at de har forstått dette og forstår hva det er, de kan begynne på oppgave fire”. På samme måte framhever praksislærer at det er stor nivåforskjell blant elevene, noe som følgende ytring illustrerer: 51. MP1: "Det så dere jo når vi var inne (stor nivåforskjell), noen tar det sånn (knipser), mens andre trenger mye mer tid og mye mer forklaring”.

I den andre matematikkgruppen når samtalen kommer inn på observasjoner i timen, blir det tydelig at studentene ikke ser sammenhengen mellom forskningsspørsmål, aktiviteter i timen og observasjoner

80. MS5: Det blir litt annerledes enn hva vi har hatt før, nå blir det jo så å si en som har hele timen, de andre sitter som passive tilskuere, eh, så hvordan det går blir jo litt spennende og se

137. MS5: Vi har jo snakket om det meste, det vanskeligste for oss, som blir veldig annerledes for denne timen, er jo det at det skal sitte tre stykker og helst ikke blande seg inn

138. MP2: Mhm

139. MS5: Og hvis jeg blir satt til observasjon, så tror jeg det blir vanskelig for min del hvis jeg ser at det sitter tre stykker og rekker opp hånden og jeg ikke bare kan reise meg opp og gå bort og faktisk gjør det jeg skal, og heller gjøre det jeg skal gjøre

I den tematiske sekvensen fra samtalen som er vist over, kan det tyde på at denne studenten ikke har helt klart for seg hvordan observasjon skal brukes for å skaffe denne informasjonen om elevenes forståelse for det faglige målet. Hun uttrykker at de tre studentene som ikke skal undervise "sitter som passive tilskuere” (80). Vi legger merke til at hun også gjentar dette i to ytringer litt senere i samtalen som vi har valgt å knytte til den tematiske sekvensen om 
observasjon (137), (139). Disse ytringene indikerer en begrensning med tanke på å samle inn informasjon om elevenes læring. De tre andre studentene er forholdsvis passive under veiledningssamtalen og det kommer ikke fram andre aspekter knyttet til gjennomføringen av observasjon i timen.

\section{Prediksjon - forventninger til elevenes forståelse}

I naturfaggruppene har også prediksjon av elevers forståelse en sentral plass i veiledningssamtalene. Dette er illustrert med følgende sekvens fra samtalen under:

99. NP1: Men hvorfor med den her gni hendene, hva forventer du at de så skal .(.) hva forventer du av elevene skal si om energioverføring? (E, K)

100. NS4: Når de har. Altså vi skal jo repetere de typene av energi i begynnelsen. Det tror jeg at vi skrev. Som vi hadde om på slutten av sist naturfagstime, så jeg tror at, i hvert fall med hjelp, at ungene kan se hva slags type energi, du må kanskje spør også, men jeg tror de klarer å forstå bevegelsesenergi. Og hvis de sier at det blir varmt, hva slags type energi tror dere det er. Det er jo nødt til å være varmeenergi. Jeg tror at de klarer det på den, at de kjenner det på seg selv. Og så hører de lyd, og det er jo deres bevegelse, og da er det lett å forstå at det er bevegelsesenergi. (E, K)

101. NS1 Meningen er jo etter denne her.(.) det her med de hendene, prosessen er jo at vi skal snakke om det felles også da, og så gå gjennom disse begrepene. Slik at de tester selv, får lov å tenke, og så etter på tar vi det sammen. Det er jo veldig viktig. Få lov å tenke selv og så (E, V)

102. NS3: Jeg tror egentlig at de kan mer. (.) eller det merket jeg på den første timen. De kan ganske mye, så det er logisk for dem, eller akkurat det med varme, men akkurat lyd, det visste jeg ikke engang. (.) så det kan være at de reagerer, eller om de ikke tenker på det. (E, K)

Dialogen fra denne praksisgruppen (skole 1) illustrerer at flere av studentene responderer på praksislærerens spørsmål om prediksjon med tanke på elevers forståelse for energioverføring (99). Den ene studenten sier at de først skal repetere ulike energityper og knytter dette til forrige undervisningsøkt. Deretter skal de fokusere på begrepene varmeenergi og bevegelsesenergi (100). I den neste ytringen konkretiserer NS1 dette gjennom aktiviteten "gni hendene" der elevene først skal undre seg og tenke selv på hva som skjer i denne prosessen før studentene sammen med elevene skal diskutere hva som skjer (101). NS3 følger opp de to foregående ytringene der hun forsøker å predikere hva som kan være vanskelig med lydenergi, men at varmeenergi er noe som trolig vil være enklere å skjønne for elevene (102). Denne refleksjonen fra NS3 er relatert til erfaringer fra en tidligere undervisningsøkt, men vi legger også merke til hennes erkjennelse om egne erfaringer: “akkurat lyd, det visste jeg ikke engang” (102). Når dette kan være vanskelig for denne studenten, så kan det sannsynligvis også være vanskelig for elevene.

I den andre praksisgruppen (skole 2) skal studentene fokusere på energiloven og studentene er særlig opptatt av å få innsikt i elevenes eventuelle feil- eller vrangforestillinger om energibegrepet, og hvordan de kan kartlegge disse. 
23. NS5: Jeg tror det er viktig å prøve å finne ut hva slags forestilling de faktisk har og så, ja prøve å kanskje ... Først avlære det på en måte hvis de har en helt feil forestilling, før vi kan begynne å lære dem noe nytt. (E, K)

24. NP2: Hva tid kan dere få vite det?

25. NS6: Går jo an å bruke tankekart for eksempel. (E, V)

26: NP2: Ja, fordi jeg tenker den timen som dere planlegger før, der har dere muligheten til å avdekke de forestillingene som elevene har. (E, V)

27. NS7: Da har vi jo og planlagt for eksempel et annet tankekart, utarbeidet gjennom timen

Her ser vi at alle tre studentene, sammen med praksislærers spørsmål, involveres i samtalen. Ytringene kan relateres til et elev- og vurderingssentrert perspektiv hvor studentene, gjennom sin undervisning forsøker å lære mer om hva elevene tenker og forstår. Ifølge Bransford et al. (2000) vil en slik måte å arbeide på hjelpe både elever og lærere i å ha innsikt i hvordan utviklingen foregår. Diskusjonen om elevene forestillinger i tilknytning til dette emnet holdes ved like gjennom hele samtalen.

Analyser av ytringer i veiledningssamtalene i matematikk viser at studentene i liten grad predikerer hva som kan være vanskelig for elevene. Praksislærer ved skole 2 (MP2) utfordrer innledningsvis i samtalen til å få de fire studentene til å reflektere over hvordan de vil gjøre algebra konkret for elevene siden det er flere elever i klassen som opplever dette vanskelig:

26. MP2: Mhm. Eh, vil det, eh, algebra eh, i intervjuet så sa jo jeg at algebra er et lite konkret emne i matematikken som de [elevene] på en måte ikke føler sånn et veldig nært forhold til, og opplever som veldig vanskelig, eh, vil dere tro eh, det er jo ulike nivåer her i klassen, hvordan vil dere gå frem for å hente frem kunnskapen om algebra hos de aller fleste? (.) Og er det muligheter for misforståelser og uklarheter i dette her? (E, K)

27. MS5: Det er det jo absolutt. Men det jeg tenker i hvert fall at faktorisering er et ganske konkret altså en konkret del av algebra.

28. MP2: Mhm

29. MP5: Det er ganske straight forward

55. MP2: Jah, eh, der hvor der kommer inn, sånn som dette uttrykket med $8 b^{2}-4 a b$, eh, vil der hvor du har $\mathrm{b}^{2}$, og for så vidt og det første uttrykket med $36 \mathrm{x}^{2}$, eh, tror dere det er greie uttrykk for basiselevene? Og $(\mathrm{E}, \mathrm{K})$

56. MS4: Når vi hadde dette i høst, så skjønte de jo at $\mathrm{x}^{2}$ betydde at det var $\mathrm{x}$ gange $\mathrm{x}$. Det er antall ganger det ganges med seg selv, så når det var $b^{3}$, så skreiv de $b$ tre ganger $(\mathrm{E}, \mathrm{K}, \mathrm{V})$

57. MP2: Mhm

58. MS5: Der er jo de oppgavene på det som heter basisnivået i boken som jeg har brukt, og vi må nok repetere det.

Praksislærer viser til intervjuet som studentene hadde med henne i forkant av førveiledningen der hun med sin elev- og kunnskapssentrerte ytring utfordrer 
studentene til å reflektere over de individuelle forskjellene det er i denne klassen med tanke på å forstå algebra (26). Vi ser imidlertid at MS5 synes at faktorisering er en konkret del av algebra (27) og at dette er "ganske straight forward” (29). Litt senere i dialogen utfordrer praksislærer studentene til å fokusere på de to første algebraiske uttrykkene fra plandokumentet og reflektere over vanskelighetsgraden i de valgte eksemplene med tanke på basiselevene (55). MS4 viser til den forrige praksisopplæringsperioden og trekker fram at elevene da kunne regne med potenser (56). Dette er en ytring som har fokus både på elev, kunnskap og vurdering $(\mathrm{E}, \mathrm{K}, \mathrm{V})$ som gir muligheter for videre faglige refleksjoner. MS5 indikerer imidlertid at hun ikke følger dette opp siden hun er mer opptatt av oppgavene som skal gjøres med referanse til læreboken og dens inndeling i ulike oppgavenivåer (58).

I denne matematikkgruppen er svært mange av ytringene (28 av 193 ytringer, 14,5\%) i veiledningssamtalen knyttet til elevenes faglige nivå i matematikk. Fremfor å være opptatt av hvordan å få innsikt i elevers ulike forståelse for algebra og hvordan dette forholder seg til hva elevene skal lære, brukes mye av tiden til å diskutere aktiviteter og oppgaver i forhold til elever som er på ulike nivå, slik som disse utsagnene under kan illustrere:

51.MS5: Eh. Så jeg ser for meg at hvertfall de som ligger på middels kan klare å være med på denne oppgaven

52 MS7: og for det om de på basis viser akkurat så mye deltakelse at de kanskje bare kan se litt og på en måte høre hvordan andre elever tenker

53 MS5: Det er greit å få det med seg

54 MS7: Ja, uansett om det på en måte ikke akkurat er noe mål at vi skal, hadde basiselevene forstått så hadde det jo vært veldig flott.

\section{Oppsummering og drøfting}

Analysen fra veiledningssamtalene i naturfag viste at studentene hadde en annen tilnærming til forskningstimen enn studentene tilknyttet matematikk. Naturfagstudentene var opptatt av både å formulere gode læringsmål og forskningsspørsmål (i den ene gruppen). En sentral del av forskningstimen som ble planlagt i naturfag var elevenes utforsking av faglige problemstillinger i grupper, uten at nivåinndelinger som basis, middels eller høy ble brukt. Elevenes ulike forforståelser ble her ikke trukket inn som en begrensende faktor i planleggingen av undervisningsopplegget. Studentene hadde også fokus på prediksjon samt aktiv elevobservasjon under gjennomføringen av undervisningsøkten. Den ene samtalesekvensen fra en av naturfaggruppene illustrerer særlig hvordan studentene kom med ytringer som bygde på tidligere initiativ og som videreførte den faglige diskusjonen knyttet til naturfaglige begreper som energi og energikjeder. Selv om det er vanskelig å synliggjøre det fellesskapssentrerte perspektivet (Bransford et al., 2000) på ytringsnivå, så illustrerer dette at 
studentene er opptatt av en fellesskapsorientert praksis gjennom at elevene skal drøfte og samhandle.

Mens studentene i naturfag la opp til en problemløsningsorientert tilnærming til de faglige læringsmålene for timen, valgte studentene i matematikk å legge undervisningen opp i forhold til lærebokens nivåinndeling av lærestoffet. Lærebøker har tradisjonelt vært en sentral kulturell ressurs i undervisningen og i evalueringen av Kunnskapsløftet vises det til at mange lærere opplever at de er blitt mer avhengige av lærebøkene i undervisningen (Hodgson, Rønning \& Tomlinson, 2012). I en delrapport (Rønning et al., 2008) finner forskerne at læreverkene på grunnskolenivået forsøker å tilrettelegge for tilpasset opplæring gjennom differensiering av lærestoffet. Samtidig stilles det i rapporten kritiske spørsmål ved lærebøkenes inndeling av lærestoff med tanke på ulike grupper av elever. Studentenes ulike tilnærminger kan ha sammenheng med hva som er dominerende praksiser ved skolen de har sin praksisopplæring. Når studentene i matematikk støtter seg på læreboken og lærebokens nivåinndeling av lærestoffet, så kan dette være som en følge av den situerte praksisen de blir deltakere i som studenter ved de to praksisskolene.

Resultatene vi har presentert viser også at det å implementere nye praksiser i lærerutdanninger er krevende. Forskjeller mellom gruppene som hadde praksisopplæring i matematikk og i naturfag kan muligens forklares av at studentene i matematikk ikke hadde faglærere på campus som ga dem innføring i Lesson Study for matematikk. Dette fraværet kan muligens være en forklaring på hvorfor studentene ikke utviklet forskningsspørsmål eller arbeidet med prediksjon slik Lesson Study intervensjonen vektla. På mange måter gjennomførte de planlegging og veiledningssamtalen mer i likhet med det som foregikk i kontrollgruppen våren 2012 enn det som var intensjonen i intervensjonen. Det er derfor viktig å understreke utdanningsinstitusjonens ansvar i å forberede studentene i forkant av en praksisopplæringsperiode med tanke på å sette dem i stand til å utvikle egen kompetanse til å gjennomføre studier av undervisning.

Studentene i denne studien er forholdsvis ferske som lærerstudenter. De er i det fjerde av totalt åtte semestre. Resultater fra studien viser også at det å utforme forskningsspørsmål og å identifisere hva som er viktig å observere er vanskelig uten god støtte fra faglærere og praksislærere. Slik sett får resultatene fram behovet for å tenke progresjon i utvikling av kompetanse for å studere og utvikle undervisning. Vi kan ikke forvente at alle studenter "kan” Lesson Study etter å ha forsøkt en gang. Å kvalifisere til forskningsbasert yrkesutøvelse krever mer og kan også omfatte studier av undervisning som foregår i større grad på campus ved hjelp av videoopptak. På denne måten kan faglærere bidra til å styrke lærerstudenters muligheter for å utvikle profesjonell kompetanse som de vil ha bruk for i framtidig læring.

Denne studien er forholdsvis liten med analyser av kun totalt fire førveiledninger (to fra hvert fag). I analysene har vi imidlertid grundig identifisert og talt alle ytringene fra veiledningssamtalene innen tre kategorier 
(E-K-V) og mener at det er noen interessante forskjeller som trer fram. Har matematikkfaget en større tendens til nivådifferensiering enn naturfag? Hva kan være årsaker til dette, og ikke minst: hva kan være konsekvenser?

Hargreaves og Fullan (2012) definerer profesjonell kapital som summen av individuell human kapital (utdanning, talenter, og lignende) pluss sosial kapital (interaksjonsmønstre mellom lærere som har fokus på elevers læring) pluss beslutningskapital (kompetanse, vurderingsevne, innsikt). Systematisk felles utforsking av konsekvenser av egne avgjørelser og antakelser (prediksjoner) kan være en måte å styrke utvikling av profesjonell kapital. Denne studien viser noe av potensialet, men også noe av utfordringene som viste seg ved implementering av Lesson Study som metode i lærerstudenters praksisopplæring.

\section{Referanser}

Bransford, J.D., Brown, A.L., \& Cocking, R.R. (2000). How people learn.Washington, DC: National Academy Press.

Elipane, L. (2011). Incorporating lesson study in pre-service mathematics teachers education. I B. Ubuz. (red.), Proceedings of the $35^{\text {th }}$ Conference of the International Group of the Psychology of Mathematics Education (Vol. 1, 305-312). Ankara, Turkey: PME.

Feiman-Nemser, S., \& Buchman, M. (1985). The pitfalls of experience in teacher education. Teachers College Record, 87(1), 53-65.

Følgegruppen (2013). Drivkraft i utviklinga av lærerprofesjonen? Framsteg og utfordringar for Grunnskulelærarutdanningane. Rapport nr. 3 fra Følgjegruppa for lærerutdanningsreforma. Hentet fra: http://ffl.uis.no/getfile.php/F\%C3\%B8lgegruppen\%20for\%201\%C3\%A6rerutdanningen\% 20\%28FFL\%29/Rapport\%20nr\%203\%20-\%20fr\%C3\%A5\%20F\%C3\%B8lgjegruppa.pdf

Hargreaves, A. \& Fullan, M. (2012). Professional capital. Transforming teaching in every school. London \& New York: Routledge.

Helgevold, N., Næsheim-Bjørkvik, G., Østrem, S. (2013). A comparison of content in mentoring sessions in two circumstances, a control group and a Lesson Study intervention group. Presentation at The World Association of Lesson and Learning Studies (WALS) International Conference, University of Gothenburg, Sweden, September, 6-8, 2013.

Hodgson, J., Rønning, W., \& Tomlinson, P. (2012). Sammenhengen mellom undervisning og lcering. En studie av lereres praksis og deres tenkning under Kunnskapsløftet.

Sluttrapport NF- rapport nr. 4/2012. Hentet fra: http://www.udir.no/Tilstand/Forskning/Rapporter/Nordlandsforskning/Undervisning-oglaring-i-Kunnskapsloftet/

Kunnskapsdepartementet (2010). Forskrift om rammeplan for grunnskolelcererutdanningene for 1.-7. trinn og 5.-10. trinn (Kunnskapsdepartementet, Rundskriv F-05-10) hentet fra: http://www.regjeringen.no/pages/2263054/Forskrift_rammeplan_grunnskolelaererutdanni ngene.pdf.

Loughran, J.J., Berry, A.K., \& Mulhall, P. (2012). Understanding and developing science teachers' pedagogical content knowledge. (2. Utgave) Rotterdam: Sense Publishers.

Munthe, E. \& Postholm, M.B. (2012). Læreres profesjonelle læring i skolen. I M.B. Postholm, P. Haug, E. Munthe \& R. Krumsvik (red.), Leerere i skolen som organisasjon (s. 137-156). Kristiansand: Cappelen Damm Høyskoleforlaget.

Munthe, E., Baugstø, T., \& Haldorsen, A. K. (2013). Japanske takter i Bømlo kommune. Bedre skole, 1, 11-15. 
Munthe, E. \& Rogne, M. (2015). Research based teacher education. Teaching and Teacher Education, 46, 17-24.

Murata, A., \& Pothen, B.E. (2011). Lesson study in pre-service elementary mathematics methods courses: Connecting emerging practice and understanding. I L. Hart, A. Alston, \& A. Murata (red.), Lesson study research and practice: Learning together (s. 103-116). Norwell, MA: Springer.

Ohnstad, F.O., \& Munthe, E. (2010). Veiledet praksisopplæring og lærerstudenters kvalifisering. I P. Haug (red.), Kvalifisering til lereryrket (s. 140-164). Oslo: Abstrakt.

Rivera, H.H. \& Tharp, R.G. (2004). Sociocultural activity settings in the classroom: A study of a classroom observation system. I H.C. Waxman, R.G.Tharp, \& R. Soleste Hilberg (red). Observational research in U.S. classrooms (s.205-230). Cambridge: Cambridge University press.

Rønning, W., Fiva, T. , Henriksen, E., Krogtoft, M.,Nilsen, N.O., Skogvold, A.S., Solstad, A.G. (2008). Læreplan, læreverk og tilrettelegging for læring. Analyse av læreplan og et utvalg læreverk i naturfag, norsk og samfunnsfag. NF-rapport nr. 2/2008. Hentet fra: http://www.udir.no/Upload/Rapporter/EvaKL/5/delrapport_1_nordforsk.pdf?epslanguage $=$ no

Stigler, J. W., \& Hiebert, J. (1999). The teaching gap. New Your, NY: The Free Press.

Sundli, L. (2007). Mentoring: A new mantra for Education? Teaching and Teacher Education, 23(2), 201-214. 